\title{
Emission scenarios for a global hydrogen economy and the consequences for global air pollution
}

\author{
Bas van Ruijven $^{\mathrm{a}, *}$, Jean-Francois Lamarque ${ }^{\mathrm{b}, 1}$, Detlef P. van Vuuren ${ }^{\mathrm{a}, 2}$, Tom Kram ${ }^{\mathrm{a}, 3}$, Hans Eerens ${ }^{\mathrm{a}, 4}$ \\ ${ }^{a}$ PBL - Netherlands Environment Assessment Agency, PO Box 1, 3720 BA Bilthoven, The Netherlands \\ ${ }^{\mathrm{b}}$ National Center for Atmospheric Research (NCAR), Atmospheric Chemistry Division, Global Tropospheric Modeling Group, 3450 Mitchell Lane, Boulder, CO 80301, USA
}

\section{A R T I C L E I N F O}

\section{Article history:}

Received 6 May 2010

Received in revised form 17 March 2011

Accepted 30 March 2011

Available online 22 April 2011

\section{Keywords:}

Hydrogen energy

Atmospheric chemistry

Molecular hydrogen emissions

Stratospheric ozone

Air polluting emissions

\begin{abstract}
A B S T R A C T
Hydrogen is named as possible energy carrier for future energy systems. However, the impact of largescale hydrogen use on the atmosphere is uncertain. Application of hydrogen in clean fuel cells reduces emissions of air pollutants, but emissions from hydrogen production and leakages of molecular hydrogen could influence atmospheric chemistry. This paper combines a global energy system model and a global atmospheric model to explore the range of impacts of hydrogen on atmospheric chemistry. We found that emissions of molecular hydrogen may range from 0.2 up to $10 \%$ (or $25-167$ Tg hydrogen/ $\mathrm{yr}$ ) for a global hydrogen energy system. The lower end of this range would in fact be equal to current emissions from fossil fuel combustion. Hydrogen energy use leads to a clear decrease in emissions of carbon monoxide, nitrogen oxides and sulphur dioxide, but large-scale hydrogen production from coal may lead to net increase in emissions of nitrous oxide and volatile organic compound. Compared to a reference scenario, this would lead to positive impacts on surface concentrations of carbon monoxide, nitrogen oxides and ozone. However, if hydrogen leakage would not be minimised it leads to an increase in methane lifetimes and a decrease in stratospheric ozone concentrations.
\end{abstract}

(C) 2011 Elsevier Ltd. All rights reserved.

\section{Introduction}

Hydrogen is named as a possible, attractive, energy carrier for future energy systems (Azar et al., 2003; Barreto et al., 2003; Edmonds et al., 2004; Hedenus et al., 2010; van Ruijven et al., 2007, 2008). Its strengths are that it can be produced from many primary energy sources, can be more easily stored than electricity, and allows for a very low emission of air pollutants during the end-use stage. Moreover, from a climate policy perspective, hydrogenbased energy systems allow for centralised production of hydrogen based on renewables and/or fossil energy combined with carbon capture and storage. As such, hydrogen-based energy systems form a direct alternative to electricity-based systems, and the choice between them depends on (expected) developments in technical improvements of relevant technologies and societal preferences.

The overall impact of a hydrogen-based energy system on atmospheric chemistry is uncertain. On the one hand, the use of

\footnotetext{
* Corresponding author. Tel.: +31 30274 3043; fax: +31 302744464.

E-mail addresses: bas.vanruijven@pbl.nl (B. van Ruijven), lamar@ucar.edu (J.-F. Lamarque), detlef.vanvuuren@pbl.nl (D.P. van Vuuren), tom.kram@pbl.nl (T. Kram), hans.eerens@pbl.nl (H. Eerens).

1 Tel.: +1 3034971495 .

2 Tel.: +31 30274 2046; fax: +31302744464.

3 Tel.: +3130274 3554; fax: +31302744464.

4 Tel.: +3130274 3012; fax: +31302744464.
}

hydrogen in clean fuel cells eliminates the end-use phase emission of air pollutants, such as sulphur dioxide $\left(\mathrm{SO}_{2}\right)$ and nitrogen oxides $\left(\mathrm{NO}_{x}\right)$. On the other hand, air pollutant emissions could still occur during hydrogen production (see Section 3). More importantly, some studies have claimed that large-scale emission of molecular hydrogen from system leakages could also lead to enhanced climate change (Derwent et al., 2006) or influence the chemical composition of the atmosphere (Price et al., 2007; Sanderson et al., 2003). Such changes may lead, for instance, to a severe reduction in stratospheric ozone concentrations (Tromp et al., 2003). Other studies, however, claim overall positive impacts on tropospheric air quality (Schultz et al., 2003). The uncertainty about the atmospheric consequences of large-scale hydrogen use is obviously important in deciding whether such a system would be attractive or not. In that respect, it should be noted that current studies into the air pollution impacts of large-scale hydrogen use tend to have used very stylised scenarios: they are not based on explicit modelling of the energy system or the emissions associated with it. This is a major limitation as the expected use of hydrogen, the intensity of leakages and emissions form major sources of uncertainty.

For the current paper, we explored the air pollution consequences of large-scale hydrogen use in more detail. The paper contributes to the existing literature in two ways. First, we systematically analysed the impacts of two determining factors on hydrogen emissions: (a) the hydrogen use and (b) the leakage 
rates, in order to find out which uncertainties could have a crucial influence on the outcomes. Second, we used realistic emission scenarios that fully describe the impact of large-scale hydrogen use in the energy-system, including emissions from hydrogen production and avoided emissions from substituted energy carriers.

For this purpose, we combined two different modelling systems: a global energy model and an atmospheric chemistry model. First, the role of hydrogen in the global energy system and the related emissions have been calculated using the global energy system simulation model TIMER which was used to develop a set of widely diverging scenarios with respect to hydrogen application (van Ruijven et al., 2007, 2008). In the present study, these energy scenarios were combined with different assumptions on hydrogen emission factors. In a second step, the emission data were fed into the Community Atmosphere Model (CAM) (Lamarque et al., 2005, 2008) to determine the impacts on atmospheric chemistry.

In Section 2, we first introduce the applied models and scenarios. Next, in Section 3 we discuss the emissions associated with different steps in the hydrogen energy system. In Section 4, we subsequently discuss the impacts of these emissions on atmospheric chemistry, while finally in Section 5 the main conclusions are presented.

\section{Methods}

As a basis for the study, we used a set of energy scenarios with and without large-scale hydrogen application recently developed by van Ruijven et al. (2008, 2007). In this section, we first briefly describe the models that have been used in this study, followed by a description of the energy scenarios.

\subsection{Models}

\subsubsection{The energy model TIMER}

The TIMER 2.0 model (van Vuuren et al., 2006) is a global energy model that forms part of the IMAGE 2.4 integrated assessment model (Bouwman et al., 2006). The TIMER model is a systemdynamics energy model that simulates year-to-year investment decisions based on a combination of bottom-up engineering information and specific rules on investment behaviour, fuel substitution and technology. In the TIMER 2.0 model, demand for end-use energy is related to economic activity in five sectors: industry, transport, residential, services, and other (the latter includes energy use in the agricultural sector). The demand formulation includes autonomous and price-induced changes in energy-intensity. Energy supply is based on fossil fuels (coal, oil, natural gas), biomass, solar and wind power, hydropower and nuclear power. In the model, twenty-six world regions can trade in fossil fuels and biofuels. The production of each primary energy carrier includes the dynamics of depletion and learning-by-doing.

The hydrogen submodel in TIMER describes production, demand and technology dynamics of hydrogen-related technologies. Hydrogen can be produced from fossil energy sources (potentially in combination with carbon capture and storage, (CS), biomass, electricity and solar thermal heat. In the model, hydrogen production costs are based on capital costs, operation and maintenance costs, fuel costs, and, if relevant, $\mathrm{CO}_{2}$ capture and storage costs. Each of the production technologies can be influenced by technological learning: capital costs decline with increasing cumulative installed capacity. Hydrogen can be used in all five end-use sectors. In each of these sectors, it competes with other secondary fuels for market share, on the basis of production costs, end-use investments and infrastructure costs. The total demand for hydrogen equals the market share multiplied by the sectoral energy demand.

In terms of infrastructure, the model distinguishes two steps: transport and distribution. Transport involves the step from largescale plants to residential areas or refuelling stations. The transport step is only applied to hydrogen that is produced in large-scale facilities and includes the costs for a hydrogen transport network (e.g. pipelines or trucks). The distribution step includes the final distribution of hydrogen to the end-user, such as the small-scale networks in residential areas or the actual refuelling stations. The distribution step is applied to both large-scale and small-scale produced hydrogen (see Fig. 1).

Because the development of hydrogen transport infrastructure is expensive, it is assumed that hydrogen for stationary applications will initially only be produced from small-scale steam methane reforming plants near end-use locations. Only when hydrogen demand rises above a certain threshold, investments in large-scale infrastructure (pipelines) are made in the model; after this hydrogen for stationary applications can be supplied from both small- and large-scale hydrogen plants. The threshold to switch from small-scale to large-scale systems is assumed at $3 \mathrm{GJ} /$ capita (optimistic) to $11 \mathrm{GJ} /$ capita (pessimistic), based on data from Ogden (1999b) and Thomas et al. (1998). For the transport sector, in contrast, we assumed that hydrogen could be produced on all scales right from the start, since demand is concentrated at fuelling stations that can be supplied by truck. Finally, it is assumed that hydrogen can also be mixed into the natural-gas grid, a route that can only be supplied by large-scale production facilities.
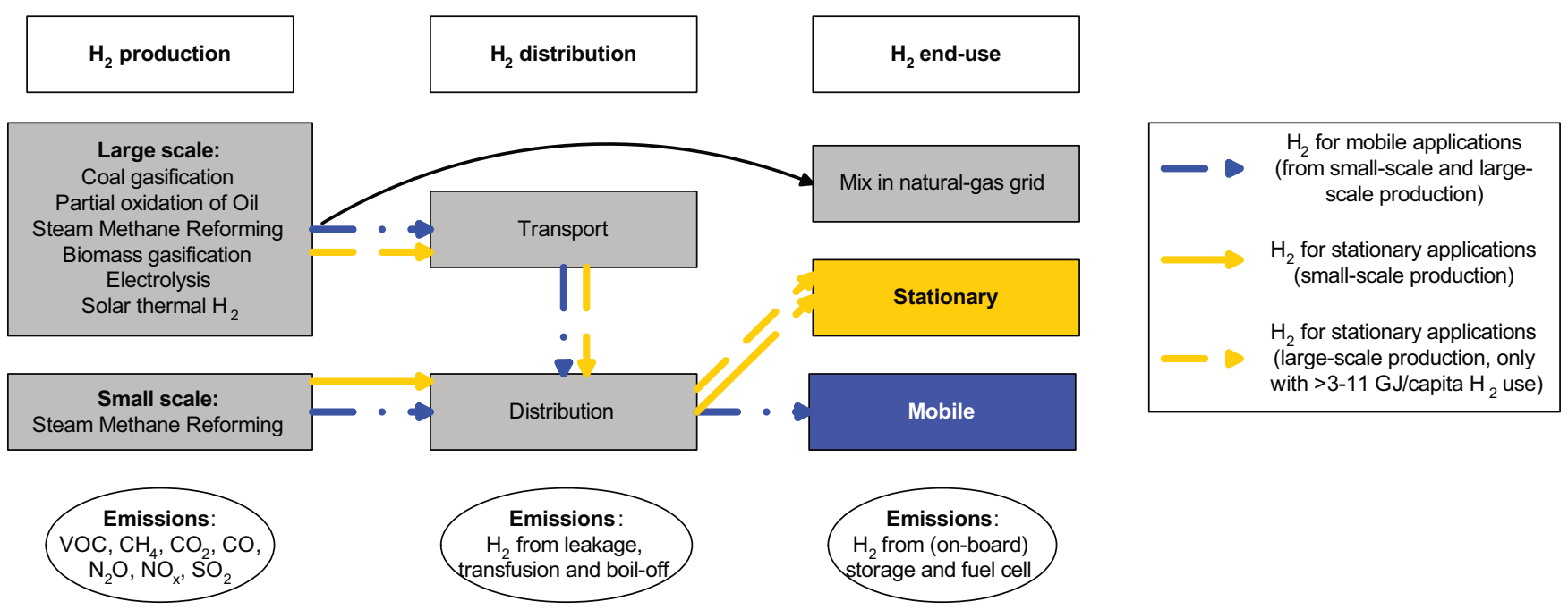

Fig. 1. Production, transport, distribution and end-use of hydrogen in the TIMER model, and emissions related to these stages in the hydrogen chain. 
Emissions are calculated in the model by multiplying energy production and consumption flows with relevant emission factors. These emission factors are derived from the EDGAR 4.0 database (European Commission Joint Research Centre (JRC)/Netherlands Environmental Assessment Agency (PBL), 2009). For $\mathrm{H}_{2}$ production and consumption, emission factors were added to the model for the purpose of this paper as is elaborated in Section 3.1.

\subsubsection{Community Atmosphere Model (CAM)}

To simulate the changes in short-lived air pollutants including aerosols, we used a modified version of the Community Atmosphere Model (CAM), version 3.5 (Gent et al., 2009). The model configuration that was used in this study included a horizontal resolution of $1.9^{\circ}$ (latitude) by $2.5^{\circ}$ (longitude) and 26 hybrid levels, from a surface level to around $40 \mathrm{~km}$ height, with time steps of $30 \mathrm{~min}$. The chemical mechanism used in this study was formulated to provide an accurate representation of both tropospheric and stratospheric chemistry (Lamarque et al., 2008). We use the representation of stratospheric chemistry from version 3 of the MOZART model (Kinnison et al., 2007); in addition our model configuration uses a representation of non-methane hydrocarbon chemistry in the troposphere, in addition to the standard methane chemistry, extended from Houweling et al. (1998) with the inclusion of isoprene and terpene oxidation and updated to JPL-2006 (Sander et al., 2006). In addition, this model includes a representation of aerosols based on the work by Tie et al. (2001, 2005), which state that sulphate aerosol is formed by the oxidation of $\mathrm{SO}_{2}$; in the gas phase by reaction with the hydroxyl radical, and in the aqueous phase by reaction with ozone and hydrogen peroxide. Additional information on the aerosol representation can be found in Lamarque et al. (2005).

At the lower boundary, the time-varying (monthly values) zonally averaged distributions of $\mathrm{CO}_{2}, \mathrm{CH}_{4}$ and relevant halocarbons (CFC-11, CFC-12, CFC-113, HCFC-22, H-1211, H-1301, $\mathrm{CCl}_{4}$, $\mathrm{CH}_{3} \mathrm{CCl}_{3}, \mathrm{CH}_{3} \mathrm{Cl}$ and $\mathrm{CH}_{3} \mathrm{Br}$ ) were specified following the datasets used in Garcia et al. (2007) and were fixed at their 2000 level. In addition, the monthly averages for the time-varying observed sea surface temperatures (SSTs) and distributions of sea ice were taken from the Hadley Centre's climatological mean (Rayner et al., 2003). Emissions of tropospheric ozone precursors and aerosols were constant throughout the simulations, and representative of the year 2000.

For this study, the Community Atmosphere Model was extended with a description of hydrogen emissions and deposition (instead of being fixed at the surface through a constant mixing ratio of $500 \mathrm{ppbv}$ in the standard configuration). The model was run with emissions for the years 2000 and 2100 for a period of 20 years to reach equilibrium in atmospheric chemistry. Only the last 5 years of each 20-year period were analysed.

In all simulations, we focused on the impact of the emissions of $\mathrm{CO}, \mathrm{NO}_{x}, \mathrm{SO}_{2}$ and $\mathrm{H}_{2}$. The rationale for this was to focus on the impact on tropospheric chemistry and surface air quality caused by changes in emissions as a result of large-scale hydrogen use. Subsequently, we studied the impact of those changes on the methane lifetime. In addition, to simplify the analysis and focus on the impact from $\mathrm{H}_{2}$ emissions and ozone precursors only, no change in climate between 2000 and 2100 was considered. Because of the limited variations in scenarios with VOC emissions (see results), all our simulations were performed using the same amount of VOC emissions. While this is clearly a simplification, it can be further justified on the fact that the change in VOC emissions discussed above only pertains to the anthropogenic portion of VOC emissions. While significant, it is only part of the very uncertain change in VOC emissions associated with climate change and $\mathrm{CO}_{2}$ effects (Young et al., 2009). This assumption of constant emissions will therefore necessitate the use of a full Earth system model to be fully addressed.

\subsection{Scenarios}

The scenarios used in this study are based on a detailed description of the energy system. This allowed us to explore the full
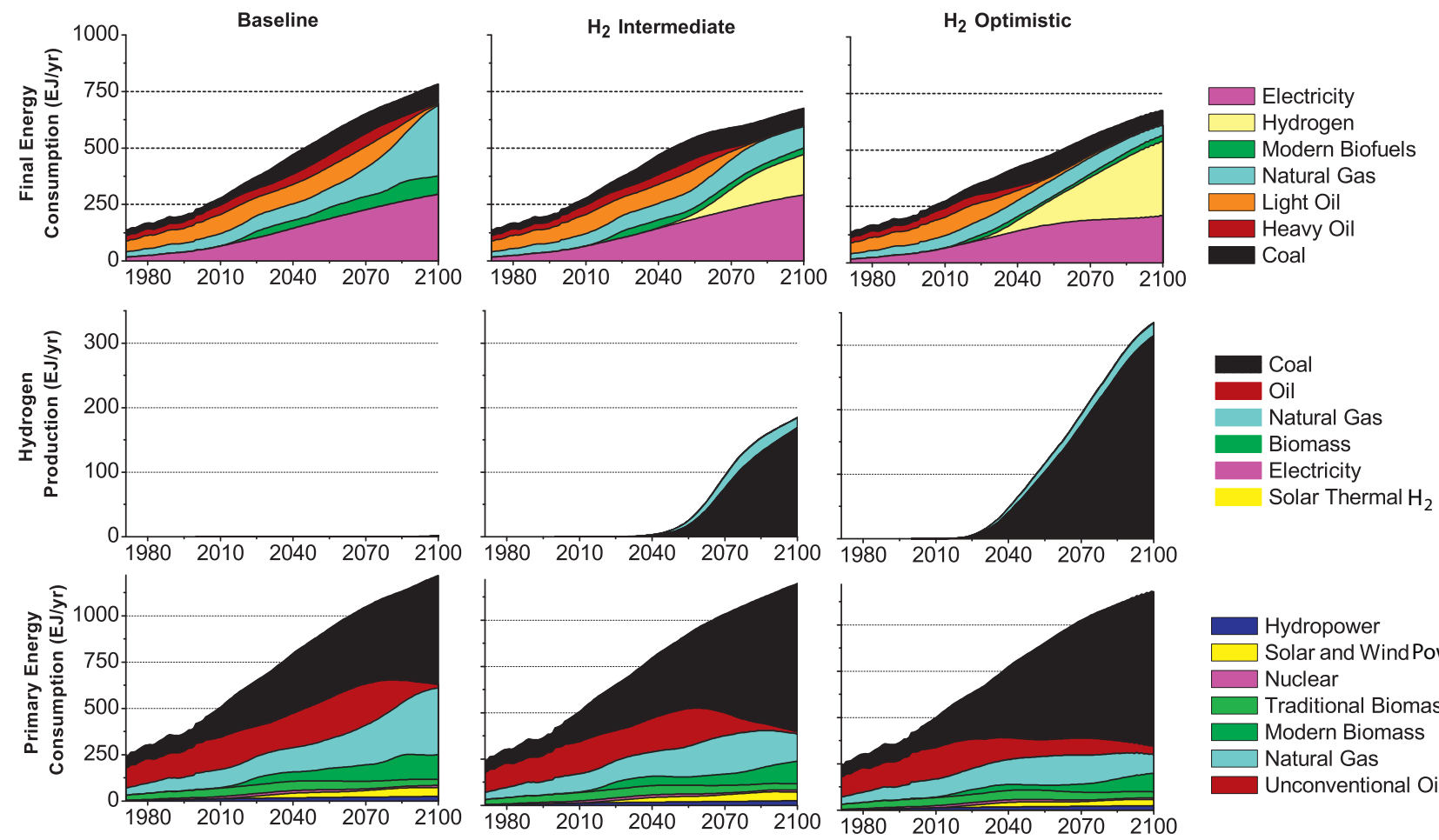

Hydropower Solar and Wind Power Nuclear Traditional Biomass Modern Biomass Natural Gas Unconventional Oi

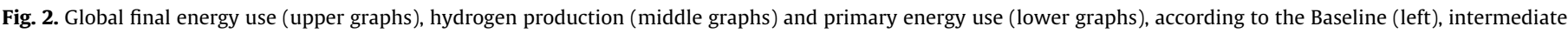
(middle) and optimistic (right) hydrogen scenarios (van Ruijven et al., 2007). 
implications of introducing hydrogen into the energy system. This is a net result of (1) the decrease in emissions of atmospheric pollutants associated with the end-use energy carriers replaced by hydrogen, and (2) the increase in emissions from hydrogen production and from leakage. As such, emission scenarios for molecular hydrogen cover the emissions from the hydrogen energy system, from fossil fuel combustion, from biomass combustion and from oceans (see also Section 3.3).

The scenarios are formulated around two important uncertainties (see also Fig. 2): (1) the hydrogen application rates (Baseline, $\mathrm{H}_{2}$ Intermediate and $\mathrm{H}_{2}$ Optimistic scenarios), and (2) the hydrogen emission factors ('leakage') in various stages of production and consumption (low leakage and high leakage scenarios).

\subsubsection{Hydrogen application rate and energy scenarios}

The application rate of hydrogen in future energy system is highly uncertain. Based on current technology, hydrogen is too expensive to become a major end-use carrier (van Ruijven et al., 2007). However, it is expected that its costs will decrease as technologies significantly improve over time. In earlier work (van Ruijven et al., 2007), we developed three scenarios based on optimistic, intermediate and pessimistic (baseline) assumptions about the technology characteristics and societal preferences that determine the application of hydrogen. In the $\mathrm{H}_{2}$ Optimistic scenario, we assumed that technology development for hydrogen production and fuel-cell technologies will reach the levels of low cost estimates in the literature as early as in 2030 . Moreover, we assumed that infrastructure development issues would be solved by that time as well. As a result, based on rapid growth rates, hydrogen would become the major energy carrier in the second half of the 21st century. In contrast, for the baseline scenario, we used pessimistic technology development rates as discussed in the literature. Under these scenario circumstances, no breakthrough would occur, and application rates would be so low that this scenario can be regarded as a no-hydrogen application scenario (or baseline). The intermediate scenario is between these two alternatives: some technology progress is made in the first half of the century, but the dilemma of infrastructure development is not solved (major infrastructure development is needed to allow large-scale hydrogen production that would induce innovation; however, these investments are only economic if hydrogen is cheap enough). van Ruijven et al. (2007) combined these hydrogen-specific scenarios with a second uncertainty: the presence of climate policy. Here, however, we decided to only look at the scenarios without climate policy (as these already provide a wide range to explore the impacts on atmospheric chemistry). In the no-climate policy scenarios, production of hydrogen is heavily based on coal (Fig. 2) as this provides the least expensive feedstock for $\mathrm{H}_{2}$ production.

\subsubsection{Emissions from large-scale hydrogen use}

Emissions of molecular hydrogen per unit of energy are uncertain. In order to explore the impact from different assumptions on hydrogen emissions in the various stages of hydrogen
Table 1

Combinations of scenarios of hydrogen use with leakage scenarios and those used in atmospheric chemistry calculations (colours indicate line colour of these scenarios in the Figures of this paper).

\begin{tabular}{lll}
\hline & Low $\mathrm{H}_{2}$ leakage rates & High $\mathrm{H}_{2}$ leakage rates \\
\hline Pessimistic & Baseline & \\
Intermediate & $\begin{array}{l}\mathrm{H}_{2} \text { Intermediate Low } \\
\text { Leakage }\end{array}$ & $\mathrm{H}_{2}$ Intermediate High Leakage \\
Optimistic & $\mathrm{H}_{2}$ Optimistic High Leakage & $\mathrm{H}_{2}$ Optimistic Low Leakage \\
\hline
\end{tabular}

production and use, we reviewed available literature on emission factors and used this to make two sets of emission factors: (1) high emission factors and (2) low emission factors. This is described in Section 3. Three scenarios of hydrogen technology development (Baseline, Intermediate and Optimistic), together with two scenarios of leakage rates (high leakage and low leakage) were combined to form a total of five scenarios (Table 1 ).

\section{Emission scenarios}

In a hydrogen-based energy system using fuel cells, hydrogen emissions may occur during the production, distribution and use of hydrogen. Emission of other air pollutants, however, can only occur in the hydrogen production phase. The emission rates during the various phases, both for hydrogen and other pollutants, are discussed below.

\subsection{Emissions of air pollutants from hydrogen production}

In contrast to the vast amount of papers on hydrogen production chains, very little information is available on the air pollutant emissions associated with each of these chains. An important reason is that most studies focus on the impact of hydrogen-based system on emissions of greenhouse gases, ignoring the impact on atmospheric pollutants (GM, 2001, 2002; Joint Research Centre, 2007). As a result, our assumptions had to be based on only a few studies (Brinkman et al., 2005; Colella et al., 2005; S\&T, 2003). Interestingly, even within this limited set of studies, a wide range of estimates was found (see Table 2).

We focused our analysis on three possible hydrogen production methods: (1) steam methane reforming (SMR), (2) coal gasification, and (3) biomass gasification (the production methods of hydrogen based on renewable energy that might be available on the long-run will not lead to emissions of air pollutants).

In general, SMR is expected to lead to considerably lower emissions of most air pollutants than the last two methods. In general, the reported emissions were indeed low, except for $\mathrm{NO}_{x}$ and CO. Still, Colella et al. (2005) indicated much lower CO and $\mathrm{NO}_{x}$ emissions than studies by S\&T Consultants (2003) and Brinkman et al. (2005). For $\mathrm{PM}_{10}$, the opposite is true - with low values reported by S\&T Consultants (2003) and very high numbers by Brinkman et al. (2005). For $\mathrm{CO}$ and $\mathrm{NO}_{x}$ from coal gasification again

Table 2

Emission factors for hydrogen production in grams per GJ fuel input.

\begin{tabular}{|c|c|c|c|c|c|c|}
\hline & \multicolumn{3}{|c|}{ Steam methane reforming } & \multicolumn{2}{|l|}{ Coal gasification } & \multirow{2}{*}{$\begin{array}{l}\text { Biomass } \\
\text { S\&T (2003) }\end{array}$} \\
\hline & Colella et al. (2005) & S\&T (2003) & Brinkman et al. (2005) & Colella et al. (2005) & S\&T (2003) & \\
\hline VOC & & 0.190 & 1.804 & & 83.597 & 9.479 \\
\hline $\mathrm{CO}$ & 0.071 & 7.583 & 8.941 & 289.574 & 7.203 & 47.393 \\
\hline $\mathrm{NO}_{x}\left(\mathrm{NO}_{2}\right)$ & 0.998 & 18.956 & 13.269 & 4.261 & 27.866 & 71.090 \\
\hline $\mathrm{PM}_{10}$ & & 0.095 & 11.218 & & 4.170 & 23.697 \\
\hline $\mathrm{SO}_{x}\left(\mathrm{SO}_{2}\right)$ & & 0.095 & & 30.062 & 27.866 & 10.750 \\
\hline $\mathrm{CH}_{4}$ & 1.033 & 0.379 & & & 8.815 & 1.896 \\
\hline $\mathrm{N}_{2} \mathrm{O}$ & & 0.284 & & & 1.232 & 3.791 \\
\hline
\end{tabular}


a wide range was reported (with $\mathrm{NO}_{x}$ values similar to SMR - and CO potentially much higher). In the studies, there was little reported variation in sulphur emission estimations: available studies used values around $30 \mathrm{~g} / \mathrm{GJ}$ input, which can be regarded as rather low compared to unabated emissions of $230-525 \mathrm{~g} / \mathrm{GJ}_{\text {input }}$ for electricity production from coal (Graus and Worrell, 2007). The values for biomass are different from coal as a result of the differences in feedstock. While reported $\mathrm{PM}_{10}, \mathrm{NO}_{x}$ and $\mathrm{CO}$ emissions are considerably higher, $\mathrm{SO}_{2}, \mathrm{VOC}$ and $\mathrm{CH}_{4}$ emissions are lower.

Emission levels from hydrogen production with carbon capture and storage are unknown. For SMR, it may be assumed that the emission levels of air pollutants other than $\mathrm{CO}_{2}$ are similar, as carbon is likely to be captured from the pure $\mathrm{CO}_{2}$ stream of reforming rather than from the combustion gases. For other hydrogen production technologies we were unable to obtain any information. For consistency, we decided to completely use the data set from the study by S\&T (2003), because their database reports on emission factors for all air pollutants.

\subsection{Leakage of molecular hydrogen during transport, distribution and end-use}

\subsubsection{Long-distance transport: hydrogen ships or HVDC cables}

Transport of the secondary fuel hydrogen over long distances is expensive, compared to the transportation of primary energy carriers. Therefore, it is unlikely that large amounts of hydrogen are transported over long distances. However, if at remote locations hydrogen can be produced from renewable energy sources (hydro-electricity, wind power or geothermal energy), large-scale transport may be still more attractive than that of highvoltage electricity (Stiller et al., 2008). In such situations, Stiller et al. (2008) indicate that transporting liquid hydrogen by sea is an attractive transportation option for distances of more than $2000 \mathrm{~km}$. Although the associated energy loss would be rather high (4.8\% for a $2400 \mathrm{~km}$ trip), some of the evaporated hydrogen could be used as fuel and would not necessarily be emitted to the atmosphere (Stiller et al., 2008). However, still the amount of evaporated hydrogen is greater than the required amount of energy for the ship so that $2-3 \%$ of the hydrogen might be emitted, depending on the transport distance and configuration of the system (Hyways, 2006; Stiller, personal communication).

\subsubsection{Liquid hydrogen in trucks and trains}

With respect to hydrogen transport in liquid form by trucks or trains, the major source of leakage is boil-off loss during transfusion. Estimations for these emissions from the transfusion process currently vary between 3 and 5\% (Air Products, personal communication; Specht et al., 1998). Emissions from boil-off during road and railway transport are estimated at $0.05 \%$ per day (Specht et al., 1998).

\subsubsection{Pipelines}

Pure hydrogen can be transported and distributed either through dedicated $\mathrm{H}_{2}$ pipelines or retrofitted natural gas pipelines. Using dedicated pipelines involves hardly any leakage, i.e. about 0.1\% (Colella et al., 2005; Schultz et al., 2003). However, hydrogen leakage rates from using (retrofitted) natural gas infrastructure can go up to 10 or $20 \%$ (Schultz et al., 2003). Because hydrogen pipelines are more expensive than retrofitted natural gas pipelines, it is useful to look into the economics of hydrogen leakages: what leakage rate from retrofitted pipelines would still be economically feasible before replacing them by $\mathrm{H}_{2}$ pipelines would become more attractive? For this purpose, we used data from Amos (1998), Ogden (1999a) and Stiller et al. (2008) to compare the costs of natural gas infrastructure with hydrogen infrastructure for distances of 10 and $650 \mathrm{~km}$. Generally, these authors estimated dedicated hydrogen infrastructure to be $50-80 \%$ more expensive than retrofitted natural gas pipelines. We have expressed the costdifference as percentage of the hydrogen production costs, to identify the leakage rate at which both infrastructures break even.

Currently, the costs involved in large-scale hydrogen production would be at least 8-10 USD/GJ (National Research Council, 2004; van Ruijven et al., 2007). At this production cost level, the price of retrofitted pipelines would allow for leakage rates of 5\% (long-distance transport) or 10-15\% (short-distance transport) for them to still be economically feasible, compared to the use of dedicated pipelines. As these leakage rates are lower than expected (i.e. the 10-20\% expected by Schultz et al. (2003)), it can be concluded that distributing (pure) hydrogen through natural gas pipelines is currently not an attractive option. However, if hydrogen production becomes cheaper in the long-term future, the economics may become different. Nevertheless, we consider it not unlikely that there would be a switch to retrofitted infrastructure at some point in the future, once, in the initial phase of a transition, developing dedicated hydrogen infrastructure would be deemed the most attractive option.

Mixing low concentrations of hydrogen (up to $6.6 \%$ on mol basis (Tabkhi et al., 2008)) in the existing natural gas grid is considered an attractive option for decreasing the carbon content of natural gas and for stimulating the development of a hydrogen energy system (Smit et al., 2007; Zachariah et al., 2004). Data on leakages of this method are not available, but the permeability of hydrogen used in non-retrofitted, natural-gas pipelines is likely to be rather high.

\subsubsection{On-board storage and venting of fuel cell stacks}

The on-board storage of hydrogen in the form of liquid hydrogen tanks may also carry a high leakage rate. Boil-off from these tanks is estimated at between 0.3 and $0.5 \%$ (de Wit and Faaij, 2007; Sherif et al., 1997) and 2-3\% per day (Amos, 1998). Assuming a linear fuel use and an average fuelling period of 7 days, this means that leakages from liquid hydrogen storage would be between 1.2 and $12 \%$ from the initial fuel tank content. It is, however, not likely that such amounts of hydrogen would be emitted directly to the environment (Zittel, 2004), as liquid hydrogen tanks are constructed to have an autonomy period of several days during which period no hydrogen is vented if pressure increases, given the enormous safety risks involved. Also, the boiloff is lead through a catalytic burner in order to prevent direct emission of hydrogen (Stiller, personal communication).

Furthermore, fuel cell stacks also belong in the row of hydrogen emission sources. Most present-day fuel cells vent hydrogen and water vapour at the anode to prevent water from building up (Colella et al., 2005). This so-called 'anode purge' takes 1-3 s and occurs every 2-5 min. Concentrations of hydrogen in this venting flow are below $4000 \mathrm{ppm}$ and are closely monitored from a safety viewpoint (NedStack Fuel Cell Technology BV, personal communication). Emission of hydrogen from this source could easily be mitigated by using an afterburner. For our research, we therefore assume an emission range of $0-1 \%$.

\subsubsection{Overall chain emissions}

Some authors have estimated hydrogen leakages throughout the entire fuel chain. Colella et al. (2005) used an upper limit of $10 \%$, while Wuebbles (2008) estimated total leakage to be $7 \%$. Schultz et al. (2003) used an upper limit of $10-20 \%$, but because of economic and safety measures, they expected the actual future leakage rate to be around 3\% (see also Schultz et al., 2004).

On the basis of the leakage rates in the individual steps discussed above, it is possible to distinguish chains of high leakages and low leakages (Table 3 ). Chains of high leakage rates contain 
Table 3

Molecular hydrogen leakage rates and estimation of total chain leakage.

\begin{tabular}{|c|c|c|c|c|}
\hline Phase & & Technology & Low leakage & High leakage \\
\hline \multirow[t]{4}{*}{ Transport } & Long distance & Ship & $0 \%$ & $2 \%$ \\
\hline & & Pipeline & $0.1 \%$ & $5 \%$ \\
\hline & Short distance & Truck (transfuse and boil-off) & $2 \%$ & $5.5 \%$ \\
\hline & & Pipeline & $0.1 \%$ & $5 \%$ \\
\hline \multirow{2}{*}{\multicolumn{2}{|c|}{ End-use }} & On-board storage & $0.3 \%$ & $1 \%$ \\
\hline & & FC and on-board system & $0.1 \%$ & $1 \%$ \\
\hline \multicolumn{3}{|c|}{ Estimated chain leakage (depends on system configuration) } & $0.3 \%$ & $10 \%$ \\
\hline
\end{tabular}

more liquid hydrogen, involve more trucks and more transfuses between transport modes. The estimates resulting from our estimates of individual steps - and other studies' estimates on chain leakages compared reasonably well. We estimated the minimum and maximum chain emissions at between 0.3 and $10 \%$, depending on the configuration of the total hydrogen system. These estimates do not contain data on emissions from compressors and refuelling, but these can be expected as very low because of safety regulations.

\subsection{Emission from other processes}

Hydrogen is not only emitted because of leakages in hydrogen energy use systems, emissions also originate from combustion processes of fossil fuels and biomass burning and from oceans (in the latter case these are natural emissions). Current global (direct) emissions of hydrogen are estimated between 36 and $48 \mathrm{Tg} \mathrm{H}_{2} / \mathrm{yr}$ (see Price et al., 2007 for an overview of studies). We used the assumption of Rhee et al. (2006) on disaggregation to the different sources: $6 \mathrm{Tg} \mathrm{H}_{2} / \mathrm{yr}$ originating from oceans, $15 \mathrm{Tg}$ $\mathrm{H}_{2} / \mathrm{yr}$ from fossil-fuel burning, and $16 \mathrm{Tg} \mathrm{H}_{2} / \mathrm{yr}$ from biomass burning. In estimating future emission trends, we scaled hydrogen emissions from combustion processes with $\mathrm{CO}$ emissions; the $\mathrm{H}_{2}$ emissions from biomass burning have been coupled to land use related $\mathrm{CO}$ emissions, while the $\mathrm{H}_{2}$ emissions from fossil energy use have been coupled to the $\mathrm{CO}$ emissions from energy use (over time these in fact tend to decrease). The CO emission factor improves following the assumptions made in the existing TIMER scenario (Bakkes et al., 2008; OECD, 2008). This simple approach ignores the difference in $\mathrm{H}_{2}$ content of the various fuels (for example, coal may be assumed to have a lower hydrogen emission factor than natural gas) but provided a reasonable estimate.

\subsection{Emission scenarios}

Based on the methods described above, Fig. 3a shows the global emissions of molecular hydrogen (both from hydrogen energy use, incomplete combustion and natural sources). Increased hydrogen use in fact results in an increase in emissions, but this is a net result from increased emissions due to leakage in hydrogen energy systems and decreased emissions from combustion of fossil fuels. The resulting emissions in the different scenarios vary over a wide range. Assuming low emission factors leads to similar hydrogen emissions scenarios with and without large-scale hydrogen use (around $25 \mathrm{Tg} \mathrm{H}_{2} / \mathrm{yr}$ ). However, assuming high emission factors and high application rates leads to an increase of hydrogen emissions to $167 \mathrm{Tg} \mathrm{H}_{2} / \mathrm{yr}$. Under the $\mathrm{H}_{2}$ Intermediate scenario, hydrogen becomes an important fuel in the transport sector, which leads to emission levels in the order of 25-106 $\mathrm{Tg} \mathrm{H}_{2} / \mathrm{yr}$, depending on the emission factor. Fig. $3 \mathrm{~b}$ indicates the different emission sources. In the $\mathrm{H}_{2}$ Optimistic Low Leakage scenario, emissions from hydrogen energy use count for about 30\% of the total emissions halving the emissions from incomplete combustion. In this scenario, most emissions from hydrogen energy use occur at end-use. In contrast, under the high leakage scenarios, the emissions associated with hydrogen use in the energy system dominate the total emissions, representing $85-90 \%$ of total molecular hydrogen emissions. Over $70 \%$ of these emissions occur during the transport and distribution of hydrogen, the remainder takes place at end-use.

It should be noted that by assuming extreme values for emission factors, this study deliberately focused on a wide range of possible outcomes for hydrogen emissions. This is also illustrated in Fig. 3a by the comparison of the results from our scenarios to those from earlier studies published by Tromp et al. (2003) and Schultz et al. (2003). The results from these studies fall within the
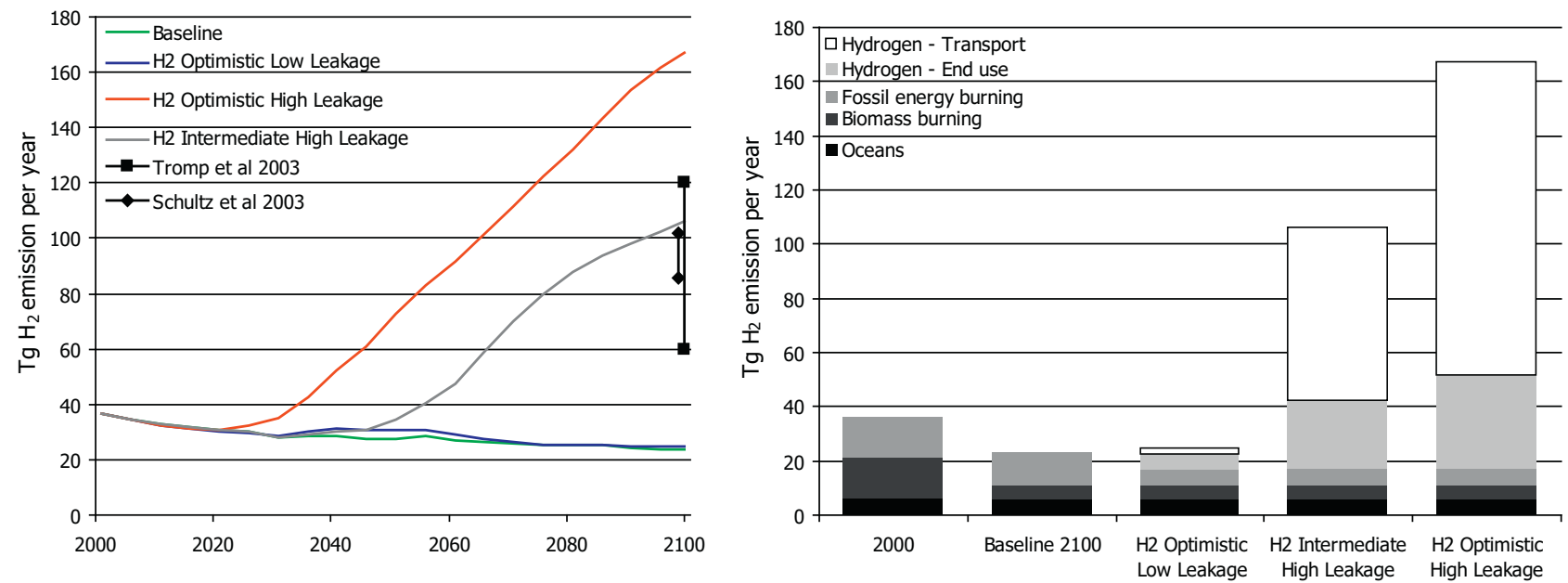

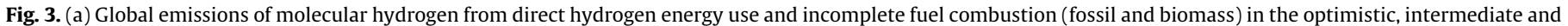

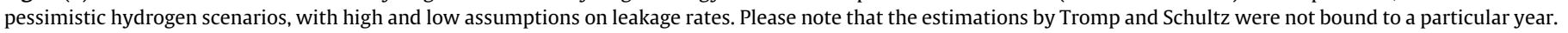
(b) Breakdown of molecular hydrogen emissions of 2000, and for the Baseline and $\mathrm{H}_{2}$ Optimistic scenarios for 2100 . Colours for the scenarios following Table 1. 
Table 4

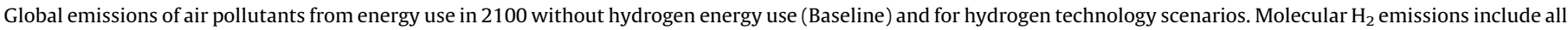
sources (fossil energy burning, $\mathrm{H}_{2}$ leakages, biomass burning and oceans).

\begin{tabular}{|c|c|c|c|c|c|c|c|c|}
\hline & $\operatorname{VOC}(\mathrm{Tg} / \mathrm{yr})$ & $\mathrm{CH}_{4}\left(\mathrm{TgCH}_{4} / \mathrm{yr}\right)$ & $\mathrm{CO}_{2}(\mathrm{GtC} / \mathrm{yr})$ & $\mathrm{CO}(\mathrm{TgC} / \mathrm{yr})$ & $\mathrm{N}_{2} \mathrm{O}(\mathrm{TgN} / \mathrm{yr})$ & $\mathrm{NO}_{x}(\mathrm{TgN} / \mathrm{yr})$ & $\mathrm{SO}_{2}(\mathrm{TgS} / \mathrm{yr})$ & $\mathrm{H}_{2}\left(\mathrm{TgH}_{2} / \mathrm{yr}\right)$ \\
\hline Historic (2000) & 60.0 & 109.0 & 7.0 & 193.7 & 0.3 & 27.7 & 54.6 & 36.5 \\
\hline Baseline 2100 & 41.9 & 465.0 & 19.6 & 166.2 & 0.6 & 68.9 & 151.2 & 23.5 \\
\hline H2 Intermediate High Leakage 2100 & 45.2 & 414.5 & 22.3 & 74.8 & 0.8 & 51.6 & 142.4 & 106.2 \\
\hline Difference with reference & $8 \%$ & $-11 \%$ & $14 \%$ & $-55 \%$ & $27 \%$ & $-25 \%$ & $-6 \%$ & $352 \%$ \\
\hline H2 Optimistic High Leakage 2100 & 67.4 & 461.7 & 23.0 & 72.5 & 0.8 & 41.4 & 108.8 & 167.1 \\
\hline Difference with reference & $61 \%$ & $-1 \%$ & $17 \%$ & $-56 \%$ & $32 \%$ & $-40 \%$ & $-28 \%$ & $611 \%$ \\
\hline H2 Optimistic High Leakage 2100 & 64.3 & 442.8 & 22.3 & 72.4 & 0.8 & 41.1 & 108.4 & 24.9 \\
\hline Difference with reference & $53 \%$ & $-5 \%$ & $14 \%$ & $-56 \%$ & $28 \%$ & $-40 \%$ & $-28 \%$ & $6 \%$ \\
\hline
\end{tabular}

wide range of scenario results drawn here. Both studies are in fact comparable to the results from our intermediate scenario with high emission factors. Obviously, the same result could also be obtained by using an optimistic hydrogen application scenario with more intermediate emission factors.

Table 4 shows the impact of hydrogen energy use on global total emissions of other air pollutants. For most air pollutants associated with fossil-fuel combustion $\left(\mathrm{CO}, \mathrm{NO}_{x}\right.$ and $\left.\mathrm{SO}_{2}\right)$, energy systems with high hydrogen application rates lead to a decrease in emissions. Methane emissions are expected to be higher in the short term, as a result of increased natural gas production as feedstock for hydrogen, but decrease towards 2100 when coal dominates the feedstock instead. $\mathrm{N}_{2} \mathrm{O}$ and VOC emissions in fact will be higher in the hydrogen scenarios in the long term, related to the high emission factors for coal gasification. The emission of air pollutants will be also somewhat higher in the high leakage scenarios than in the low leakage scenarios, because more hydrogen needs to be produced to overcome the losses due to leakages during transport and distribution.

In the remainder of this paper, four scenarios are explored further with respect to atmospheric chemistry based on their position in the emission range:

1. the baseline scenario, i.e., pessimistic hydrogen technology development and low leakage rates (virtually no hydrogen use);

2. the intermediate hydrogen technology development scenario combined with high leakage rates;

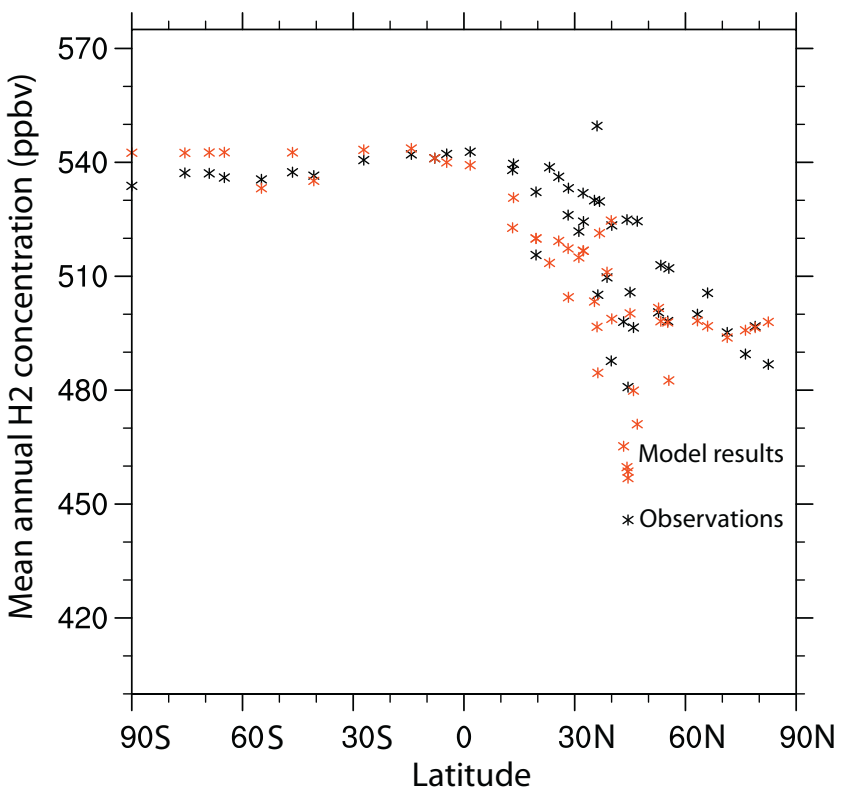

Fig. 4. Mean annual concentration (ppbv) of atmospheric hydrogen across latitudes in the year 2000, model results (red) and observations (black). (For interpretation of the references to color in this figure legend, the reader is referred to the web version of this article.)
3. the optimistic hydrogen technology development scenario combined with high leakage rates;

4. and the optimistic hydrogen technology development scenario combined with low leakage rates.

A comparison of the last two scenarios can provide insight into the impact of uncertainty on the emission factor, while a comparison of case 2-4 with the first scenario allows for an evaluation of the impact of reducing other air pollutants by introducing hydrogen into the energy system. The second scenario, finally, also enables a comparison with earlier studies by Tromp et al. (2003) and Schultz et al. (2003) given the similar emission trajectories for hydrogen. We excluded the $\mathrm{H}_{2}$ Intermediate Low Leakage scenario from further analysis, since emissions in this scenario are comparable $\mathrm{H}_{2}$ Optimistic Low Leakage scenario.

\section{Evaluation of simulated $\mathrm{H}_{2}$ and impacts on global atmospheric chemistry}

\subsection{Model calibration of the global atmospheric chemistry model}

In the first simulation, we focused on the model performance in representing the present day $\mathrm{H}_{2}$ concentrations on the basis of current emissions. For this purpose, we used global observations of $\mathrm{H}_{2}$ concentrations at surface level, as used by Hauglustaine and Ehhalt (2002), extended to incorporate all observations (through 2006) available from the NOAA Earth System Research Laboratory. ${ }^{5}$ The results show that, when the Community Atmosphere Model (CAM) was run on the basis of current emissions, the model performed well in reproducing the overall distribution of $\mathrm{H}_{2}$ at surface level, including lower concentration levels in the Northern hemisphere as a result of higher deposition rates (Fig. 4). The global mean annual lifetime for $\mathrm{H}_{2}$ in the model was around 2.3 years, which was also in very good agreement with the range of lifetimes of 1.9-2.3 years that was reported by Hauglustaine and Ehhalt (2002) and Price et al. (2007). Note that our reported lifetime is computed over the whole model domain, i.e. includes the fairly slow $\mathrm{H}_{2}$ loss in the stratosphere; when the atmospheric loss is computed over the troposphere only, then our lifetime is 1.9 years, identical to the tropospheric estimate in Price et al. (2007).

\subsection{Impact of $\mathrm{H}_{2}$ scenarios on tropospheric air quality}

In the second simulation, we focused on the impact of the various emission scenarios described in Section 3 on the surface distributions of various chemical compounds important to air quality considerations.

First of all, the results for surface concentrations of hydrogen reflect the changes between the emission scenarios (Fig. 5). Under the baseline scenario and the $\mathrm{H}_{2}$ Optimistic Low Leakage scenario, concentrations of hydrogen are below the year 2000 levels, caused by the relatively low emissions in these scenarios (Fig. 3 and Table

\footnotetext{
${ }^{5}$ See http://www.esrl.noaa.gov/gmd/dv/ftpdata.html.
} 

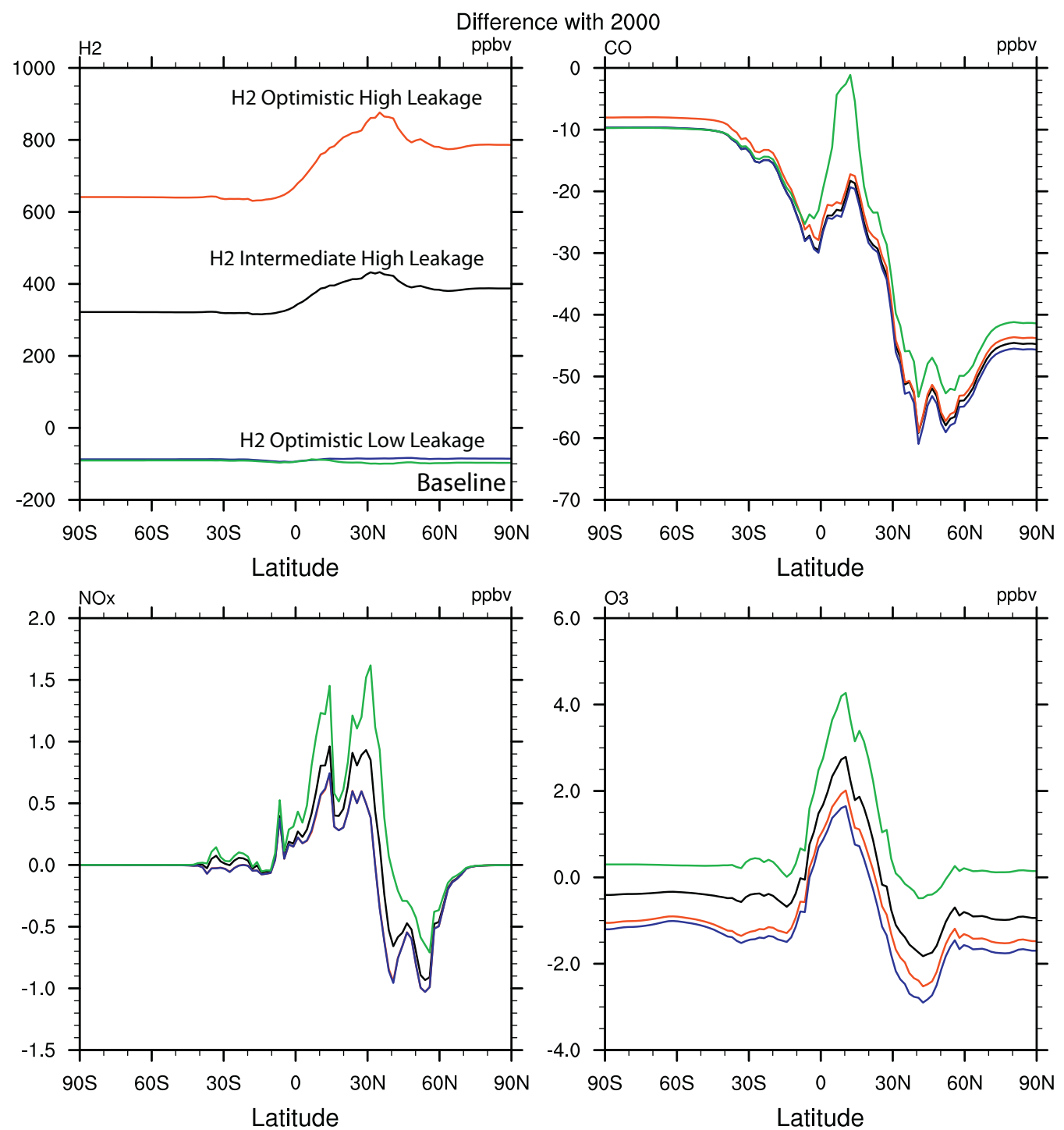

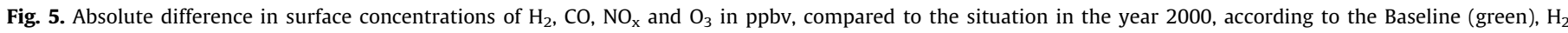

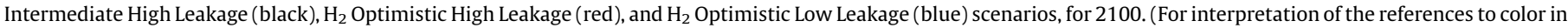
this figure legend, the reader is referred to the web version of this article.)

4). However, high application rates combined with high emission factors $\left(\mathrm{H}_{2}\right.$ Optimistic High Leakage scenario) results in almost a factor of five increase in molecular hydrogen concentrations compared to year 2000 concentrations.

For $\mathrm{CO}$, the baseline (i.e. zero-hydrogen application) already leads to a reduction in concentrations of as much as $40 \%$ in the northern mid-latitudes as result of lower emissions. The $\mathrm{CO}$ concentrations are reduced even further under all hydrogen scenarios, because of reduced emissions from avoided fossil fuel combustion.

For $\mathrm{NO}_{x}$ concentrations, trends are somewhat opposite in temperate and tropical regions. In some tropical regions, where emissions in 2000 were low, the concentrations increased in the baseline scenario. This contrasts to temperate regions, where a small decrease can be noted. Under the hydrogen scenarios, concentrations are somewhat reduced compared to the baseline in both the tropical and temperate regions. This is the result of a decrease in the combustion of fossil fuels.

The impacts from the different scenarios on the mean annual concentrations of surface ozone are quite modest. The baseline scenario shows an increase in concentration levels of a few ppbv (about 4\%), compared to the present-day concentrations in most regions. Tropical regions form an exception, with an increase of
4 ppbv, or approximately $20 \%$ in the baseline scenario. The scenarios of large-scale hydrogen use show lower ozone concentrations than the baseline scenario.

All-in-all, according to the scenarios analysed here, it can be concluded that hydrogen energy use improves air quality at surface level.

4.3. Impact from $\mathrm{H}_{2}$ scenarios on the atmospheric lifetime of methane and hydrogen

The third simulation looked into the atmospheric lifetime of methane and hydrogen. Interestingly, the results from the calculations show that the scenarios with high hydrogen emissions lead to a clear impact on the atmospheric lifetime of molecular hydrogen and methane. The lifetime of molecular hydrogen decreases by about $6 \%$ in the scenarios with high emissions of molecular hydrogen as a result of changes in atmospheric chemistry. Under the baseline and low leakage scenarios, the lifetime decreases by only 2-3\% as a result of lower hydrogen concentrations.

For the methane lifetime, the baseline scenario leads to a decrease of about $13 \%$, compared to the year 2000 situation. This is caused by a significant increase in $\mathrm{NO}_{x}$ emissions, leading to an overall increase in tropospheric ozone concentrations and, 
Table 5

Tropospheric lifetime of methane and molecular hydrogen, according to the Baseline, $\mathrm{H}_{2}$ Intermediate High Leakage, $\mathrm{H}_{2}$ Optimistic High Leakage, and $\mathrm{H}_{2}$ Optimistic Low Leakage scenarios, for 2100.

\begin{tabular}{lll}
\hline Simulation & $\begin{array}{l}\mathrm{H}_{2} \text { lifetime } \\
\text { (years) }\end{array}$ & $\begin{array}{l}\mathrm{CH}_{4} \text { lifetime } \\
\text { (years) }\end{array}$ \\
\hline 2000 emissions & 1.89 & 7.84 \\
Baseline 2100 & 1.84 & 6.78 \\
$\mathrm{H}_{2}$ Intermediate High Leakage 2100 & 1.78 & 7.26 \\
$\mathrm{H}_{2}$ Optimistic High Leakage 2100 & 1.78 & 7.73 \\
$\mathrm{H}_{2}$ Optimistic Low Leakage 2100 & 1.86 & 7.24 \\
\hline
\end{tabular}

therefore, to $\mathrm{OH}$. This impact (i.e. the shorter methane lifetime in the baseline scenario) is reduced under the scenarios with high hydrogen emissions. This effect is strongest in scenarios with higher $\mathrm{H}_{2}$ emission and lower $\mathrm{NO}_{x}$ emission. For instance, methane lifetimes in the $\mathrm{H}_{2}$ Optimistic High Leakage scenario are $14 \%$ higher than in the Baseline scenario (Table 5). This is in line with the results from Schultz et al. (2003), who found an $11 \%$ increase in methane lifetimes under scenarios with high emissions of molecular hydrogen.

This implies that hydrogen energy systems are in three aspects relevant to climate change. Hydrogen use may have a direct impact on climate change via the level of greenhouse gas emissions (see $\mathrm{CO}_{2}$ emissions in Table 4, and also van Ruijven et al., 2007), and $\mathrm{H}_{2}$ may act as a greenhouse gas itself (Derwent et al., 2006). As shown here there is also an indirect impact via the changes in the methane lifetime (Table 5). Because methane is a strong greenhouse gas (IPCC, 2007) any change to its lifetime directly impacts its overall radiative forcing. The scenarios of high hydrogen application rates and high emission factors (and thus high emissions) result in higher methane lifetimes and, thus, in more climate change. It should, however, be noted that other indirect impacts, such as those from climate conditions (the temperature and humidity conditions are valid for 2000) have not been accounted for and that direct changes in methane emissions have not been included in this analysis.

\subsection{Impact from hydrogen scenarios on ozone concentrations}

Finally, the differences in emissions under the various scenarios also impact the total ozone column. In particular, the reaction of $\mathrm{H}_{2}$ with $\mathrm{OH}$ in the stratosphere leads to the formation of water (Le Texier et al., 1988) and, subsequently, to a decrease in stratospheric ozone (Tromp et al., 2003). All scenarios lead to a decrease in stratospheric ozone. These reductions are lowest under the

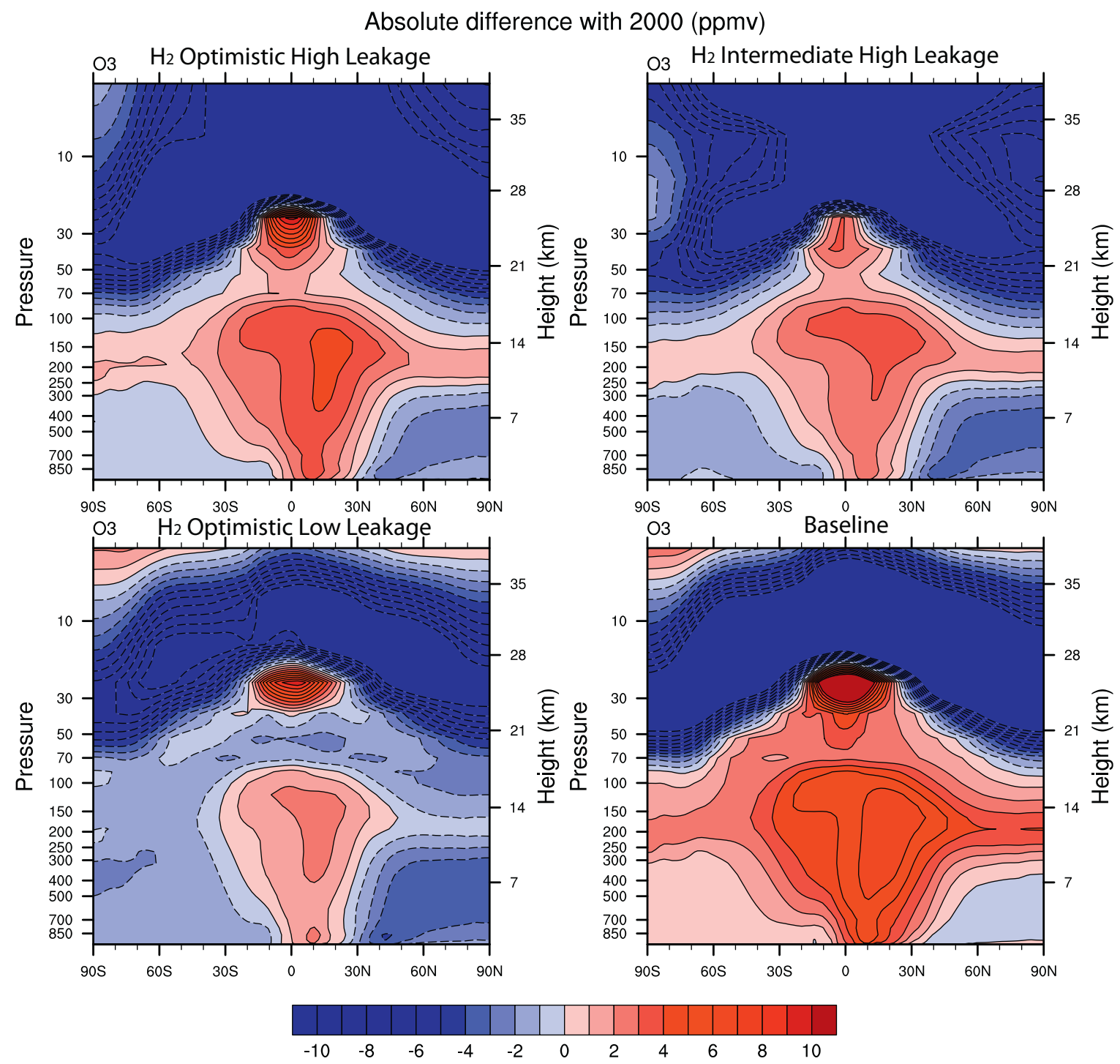

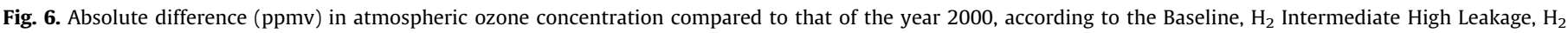
Optimistic High Leakage, and $\mathrm{H}_{2}$ Optimistic Low Leakage scenarios for 2100 


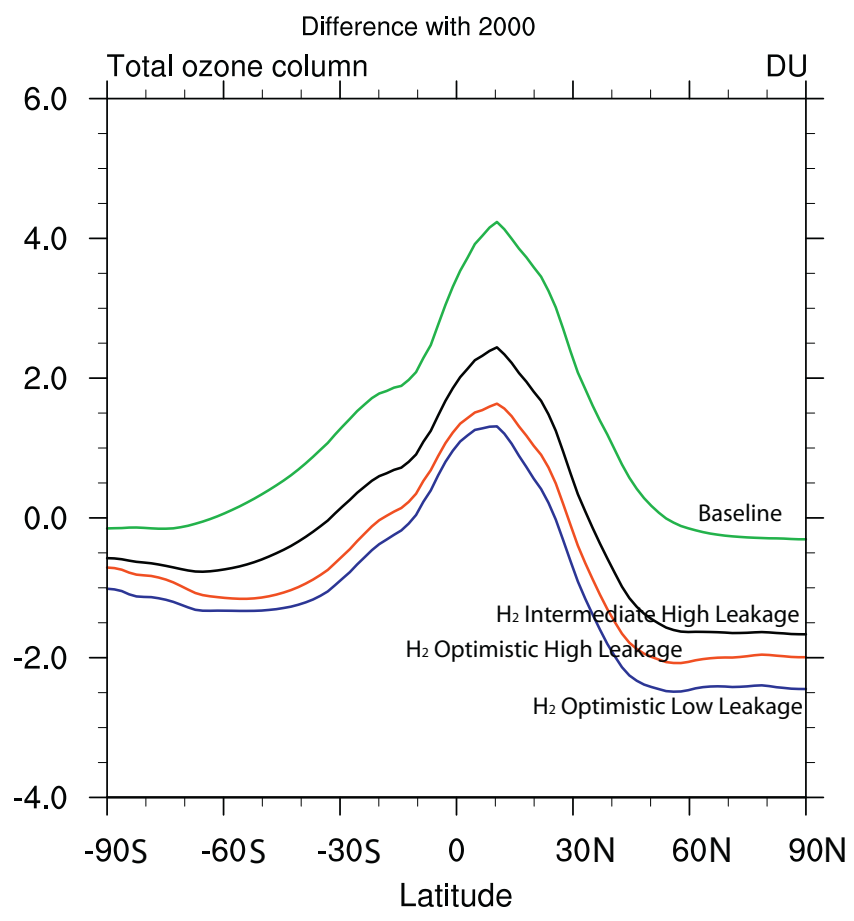

Fig. 7. Difference in total ozone column across latitudes for the Baseline (green), $\mathrm{H}_{2}$ Intermediate High Leakage (black), $\mathrm{H}_{2}$ Optimistic High Leakage (red), and $\mathrm{H}_{2}$ Optimistic Low Leakage (blue) scenarios for 2100. (For interpretation of the references to color in this figure legend, the reader is referred to the web version of this article.)

baseline and $\mathrm{H}_{2}$ Optimistic Low Leakage scenarios (which has the lowest emissions of molecular hydrogen). Similarly, the reductions of the total ozone column are larger in the scenarios with high hydrogen emissions. The overall impact on stratospheric ozone is shown in Fig. 7 by the change in the total ozone column. The maximum ozone reduction was found to be approximately 2 DU (Dobson unit) in the high latitudes. This is $<1 \%$ of the annual mean, comparable to findings by Tromp et al. (2003) and Vogel et al. (2011). The impact is, however, much smaller than the observed decrease in the Northern Hemisphere total ozone column of the 1990 s, associated with the increase in man-made chlorine in the stratosphere (Newman et al., 2007). This limited impact on the total ozone column is in fact a combination of increases (in the troposphere) and decreases (in the stratosphere), see Fig. 6. The ozone increase in the tropical troposphere is responsible for the increase in $\mathrm{OH}$ and the associated decrease in methane lifetime noted in the previous section.

\section{Discussion and conclusion}

The current literature on the impacts of large-scale hydrogen application on air pollution presents very different results: while some studies emphasize an improvement of air quality, other studies emphasize a negative impact on, for instance, the total ozone column. It should, in this context, be noted that most of this literature is based on very stylised assumptions on future hydrogen use and associated emissions. In this article, we have therefore looked in more detail into the impact of large scale hydrogen use by combining scenario calculations from a global energy model (TIMER) with calculations of an atmospheric chemistry model (CAM).

For the analysis, we have made an estimate of the emission and leakages of molecular hydrogen and emissions of other air pollutants from hydrogen production and transport. Different combinations were made of hydrogen application and possible leakage rates in order to explore the ranges of potential emissions from a hydrogen energy system.

In the scenarios, hydrogen is produced early in the century mostly through steam methane reforming and later mostly through coal gasification. If other feedstocks or technologies would be used to produce hydrogen, this would influence the emission levels of air pollutants during the hydrogen production stage. The presence of climate policy could also be an important factor, as was shown by van Ruijven et al. (2007). With stringent climate policy, hydrogen production would be based carbon capture and storage (CCS) technologies or possibly on renewable energy. This would automatically lead to lower air pollutant emissions, especially on the long-run. In this paper, however, we focussed on possible range of potential impacts by comparing scenarios without hydrogen use with those with large scale hydrogen application, in the absence of climate policy.

The analysis shows that:

- The emission factors in the literature for hydrogen production and transport systems vary over a wide range. Our analysis shows that, across the whole chain, hydrogen emissions could be between 0.3 and $10 \%$ for fully developed hydrogen energy systems. In the case of the lowest percentage, emissions of a fully developed hydrogen energy system would equal present-day molecular hydrogen emissions from incomplete fossil-fuel combustion. In the case of the highest percentage, emissions could be as high as $167 \mathrm{Tg} \mathrm{H}_{2} / \mathrm{yr}$ (i.e. 5 times today's total molecular hydrogen emissions). Both the hydrogen application rate and emission factors are important to explain the uncertainty range.

- Hydrogen use has mixed impacts on the emissions of other air pollutant, but mostly leads to lower emissions. The introduction of hydrogen into the energy system could increase $\mathrm{N}_{2} \mathrm{O}$ and VOC emissions if hydrogen would mainly be produced from coal. However, emissions of combustion-related air pollutants, such as $\mathrm{CO}, \mathrm{NO}_{x}$ and $\mathrm{SO}_{2}$, would be lower in a hydrogen energy system.

- As a result of changes in emissions, hydrogen energy systems are likely to lead to a reduction of air pollution. Compared with developments under a baseline scenario, energy systems with large-scale hydrogen use have a positive influence on surface concentrations of $\mathrm{CO}$ (especially in tropical regions) and $\mathrm{O}_{3}$.

- Large scale hydrogen application may have various impacts on climate change. The impact from a hydrogen energy system on climate change would have three components. First, there would be a direct impact on greenhouse gas emissions from fossil-fuel combustion. Second, hydrogen might act as a greenhouse gas itself, and third, the change in molecular hydrogen emissions would also influence the lifetime of methane, increasing it through the increased ozone in the troposphere. It should, however, be noted that potential feedback to the methane lifetime from changes in the emission of methane itself has not been accounted for.

- Large scale hydrogen application may have a small, negative impact on stratospheric ozone concentrations. Stratospheric ozone concentrations would decrease when molecular hydrogen emissions increase; this effect was found to be rather small, because the decrease in the stratosphere was compensated by an increase in the troposphere.

In our study, we have shown that current uncertainties imply that large-scale hydrogen use may lead to a wide range of molecular hydrogen emissions. The range considered here is, in fact, considerably wider than those in the existing literature by Tromp et al. (2003) and Schultz et al. (2003). For the high end of the range, it should be noted that both earlier estimates were based on replacing the current global fossil energy use with hydrogen, while our study accounts for energy consumption growth during the $21 \mathrm{st}$ 
century. For the lower end of the range, our estimation of leakages in the hydrogen chain was lower $(0.3 \%)$ than that of earlier studies $(\sim 1 \%)$. However, from the limited number of available cost estimations on low leakage technologies, one may conclude that it could sometimes be economically attractive to maintain high leakage rates.

The findings from this integrated analysis of the impacts of a hydrogen energy system on the atmosphere are generally in line with those from existing literature. The positive impacts on the troposphere, such as reduced levels of $\mathrm{CO}, \mathrm{NO}_{x}$ and $\mathrm{SO}_{2}$, were also identified by Schultz et al. (2003). The negative impacts on stratospheric ozone are in line with those found by Tromp et al. (2003), with a larger impact in the Northern Hemisphere than in the Southern Hemisphere. A combination of hydrogen production from coal and an increase in methane lifetimes, without proper policies, would increase the risk of hydrogen energy having a potentially negative impact on climate change.

The projected emissions of air pollutants from a hydrogen energy system are highly uncertain. Estimates of air polluting emissions from hydrogen production technologies are rare and mostly based on the current situation. It is likely that the emissions of most air pollutants become subject to stringent policies, once hydrogen becomes more widely used. However, the costs involved and the potential for such a widespread use are currently unknown.

The main limitations of the simulations in this study are those about the role of changes in methane emissions associated with the various other emissions, along with changes in climatic conditions of the year 2100 . To fully account for these variations, it would be useful to compute the impact from the various scenarios, using a fully coupled climate-chemistry model which also incorporates the methane feedbacks (including the impact on surface temperatures).

The results from this study imply that policymakers need to be aware of the potential negative effects of hydrogen energy use but that these do not seem as large as some of the earlier studies suggested. This means that additional policies on molecular hydrogen emissions and air pollutants would be required, alongside policies that promote the use of hydrogen energy technologies.

\section{Acknowledgements}

The authors thank Annemieke Righart for text editing. We also thank the other members of the IMAGE team for their contributions to this paper.

\section{References}

Air Products, personal communication. E-mail conversation between P. Bout and B van Ruijven, Bilthoven, 4 February 2009.

Amos, W.A., 1998. Costs of Storing and Transporting Hydrogen. NREL, Colorado, USA

Azar, C., Lindgren, K., Andersson, B.A., 2003. Global energy scenarios meeting stringent $\mathrm{CO}_{2}$ constraints - cost-effective fuel choices in the transportation sector. Energy Policy 31, 961-976.

Bakkes, J., Bosch, P.R., Bouwman, A.F., Eerens, H.E., den Elzen, M., Isaac, M., Janssen, P.H.M., Klein Goldewijk, C.G.M., Kram, T., de Leeuw, F.A.A.M., Olivier, J.G.J., van Oorschot, M.M.P., Stehfest, E.E., van Vuuren, D.P., Bagnoli, P., Chateau, J., CorfeeMorlot, J., Kim, Y.-G., 2008. Background Report to the OECD Environmental Outlook to 2030: Overviews, Details and Methodology of Model-based Analysis. Netherlands Environmental Assessment Agency (PBL), Bilthoven, p. 186.

Barreto, L., Makihira, A., Riahi, K., 2003. The hydrogen economy in the 21 st century: a sustainable development scenario. Int. J. Hydrogen Energy 28, 267-284.

Bouwman, A.F., Hartman, M.P.M., Klein Goldewijk, C.G.M., 2006. Integrated Modelling of Global Environmental Change. An Overview of IMAGE 2.4. Netherlands Environmental Assessment Agency, Bilthoven, The Netherlands.

Brinkman, N., Wang M., Weber, T. Darlington, T, 2005. Well-to-Wheels Analysis of Advanced Fuel/Vehicle Systems - A North American Study of Energy Use, Greenhouse Gas Emissions, and Criteria Pollutant Emissions. Argonne National Laboratory, Argonne, IL.
Colella, W.G., Jacobson, M.Z., Golden, D.M., 2005. Switching to a U.S. hydrogen fuel cell vehicle fleet: the resultant change in emissions, energy use, and greenhouse gases. J. Power Sources 150, 150-181.

de Wit, M.P., Faaij, A.P.C., 2007. Impact of hydrogen onboard storage technologies on the performance of hydrogen fuelled vehicles: a techno-economic well-towheel assessment. Int. J. Hydrogen Energy 32, 4859-4870.

Derwent, R., Simmonds, P., O’Doherty, S., Manning, A., Collins, W., Stevenson, D., 2006. Global environmental impacts of the hydrogen economy. Int. J. Nucl. Hydrogen Prod. Appl. 1, 57-67.

Edmonds, J., Clarke, J., Dooley, J., Kim, S.H., Smith, S.J., 2004. Stabilization of CO2 in a B2 world: insights on the roles of carbon capture and disposal, hydrogen, and transportation technologies. Energy Econ. 26, 517-537.

European Commission Joint Research Centre (JRC)/Netherlands Environmental Assessment Agency (PBL), 2009. Emission Database for Global Atmospheric Research (EDGAR), release version 4.0

Garcia, R.R., Marsh, D.R., Kinnison, D.E., Boville, B.A., Sassi, F., 2007. Simulation of secular trends in the middle atmosphere, 1950\&\#8211;2003. J. Geophys. Res. 112, D09301.

Gent, P.R., Yeager, S.G., Neale, R.B., Levis, S., Bailey, D.A., 2009. Improvements in a half degree atmosphere/land version of the CCSM. Clim. Dyn. 1-15.

GM, 2001. Tank-to-wheel Energy Utilization for a North American Vehicle. General Motors Corporation, p. 12

GM, 2002. Well-to-wheel Analysis of Energy Use and Greenhouse Gas Emissions of Advanced Fuel/vehicle Systems - A European Study. L-B Systemtechnik, Ottobrun, Germany, p. 130.

Graus, W.H.J., Worrell, E., 2007. Effects of SO2 and NOx control on energy-efficiency power generation. Energy Policy 35, 3898-3908.

Hauglustaine, D.A., Ehhalt, D.H., 2002. A three-dimensional model of molecular hydrogen in the troposphere. J. Geophys. Res. 107, 4330.

Hedenus, F., Karlsson, S., Azar, C., Sprei, F., 2010. Cost-effective energy carriers for transport - the role of the energy supply system in a carbon-constrained world. Int. J. Hydrogen Energy 35, 4638-4651.

Houweling, S., Dentener, F., Lelieveld, J., 1998. The impact of nonmethane hydrocarbon compounds on tropospheric photochemistry. J. Geophys. Res. D: Atmos. 103, 10673-10696.

Hyways, 2006. Technology Fact Sheets. LBST, Ottobrun, Germany.

IPCC, 2007. Climate Change 2007: Synthesis Report. Cambridge University Press, Cambridge.

Joint Research Centre, 2007. Well-to-Wheels Analysis of Future Automotive Fuels and Powertrains in the European Context.

Kinnison, D.E., Brasseur, G.P., Walters, S., Garcia, R.R., Marsh, D.R., Sassi, F., Harvey, V.L., Randall, C.E., Emmons, L., Lamarque, J.F., Hess, P., Orlando, J.J., Tie, X.X., Randel, W., Pan, L.L., Gettelman, A., Granier, C., Diehl, T., Niemeier, U., Simmons, A.J., 2007. Sensitivity of chemical tracers to meteorological parameters in the MOZART-3 chemical transport model. J. Geophys. Res. 112, D20302.

Lamarque, J.-F., Kinnison, D.E., Hess, P.G., Vitt, F.M., 2008. Simulated lower stratospheric trends between 1970 and 2005: identifying the role of climate and composition changes. J. Geophys. Res. 113, D12301.

Lamarque, J.F., Kiehl, J.T., Hess, P.G., Collins, W.D., Emmons, L.K., Ginoux, P., Luo, C., Tie, X.X., 2005. Response of a coupled chemistry-climate model to changes in aerosol emissions: Global impact on the hydrological cycle and the tropospheric burdens of $\mathrm{OH}$, ozone, and NOx. Geophys. Res. Lett. 32, L16809.

Le Texier, H., Solomon, S., Garcia, R.R., 1988. The role of molecular hydrogen and methane oxidation in the water vapour budget of the stratosphere. $\mathrm{Q}$. J. R. Meteorol. Soc. 114, 281-295.

National Research Council, 2004. The Hydrogen Economy: Opportunities, Costs, Barriers and R\&D Needs. The National Academies Press, Washington, DC.

NedStack Fuel Cell Technology BV, personal communication. E-mail conversation between S.F. Au and B. van Ruijven, Bilthoven, 23 March 2009.

Newman, P.A., Rex, M., Canziani, P.P., Carslaw, K.S., Drdla, K., Godin-Beekman, S., Golden, D.M., Jackman, C.H., Kreher, K., Langematz, U., Muller, R., Nakane, H., Orsolini, Y. Salawitch, R. Santee, M.L., Hobe, M., Yoden, v., Polar Ozone, S. 2007. Past and Present, Chapter 4 in Scientific Assessment of Ozone Depletion: 2006, Global Ozone Research and Monitoring Project. World Meteorological Organization, Geneva, Switzerland.

OECD, 2008. OECD Environmental Outlook to 2030. OECD, Paris.

Ogden, J.M., 1999a. Developing an infrastructure for hydrogen vehicles: a Southern California case study. Int. J. Hydrogen Energy 24, 709-730.

Ogden, J.M., 1999b. Prospects for building a hydrogen energy infrastructure. Annu. Rev. Energy Environ. 24, 227-279.

Price, H., Jaeglé, L., Rice, A., Quay, P., Novelli, P.C., Gammon, R., 2007. Global budget of molecular hydrogen and its deuterium content: constraints from ground station, cruise, and aircraft observations. J. Geophys. Res. 112, D22108.

Rayner, N.A., Parker, D.E., Horton, E.B., Folland, C.K., Alexander, L.V., Rowell, D.P., Kent, E.C., Kaplan, A., 2003. Global analyses of sea surface temperature, sea ice, and night marine air temperature since the late nineteenth century. J. Geophys. Res. $108,4407$.

Rhee, T.S., Brenninkmeijer, C.A.M., Rockmann, T., 2006. The overwhelming role of soils in the global atmospheric hydrogen cycle. Atmos. Chem. Phys. 6, 16111625

S\&T, 2003. The Addition of Coal and Biomass to Hydrogen Pathways to GHGenius. S\&T Consultants Inc., Delta, BC.

Sander, S.P., Friedl, R.R., Ravishankara, A.R., Golden, D.M., Kolb, C.E., Kurylo, M.J., Molina, M.J., Moortgat, G.K., Keller-Rudek, H., J.Finlayson-Pitts, B., Wine, P.H., Huie, R.E., Orkin, V.L., 2006. Chemical Kinetics and Photochemical Data for Use in Atmospheric Studies, Evaluation Number 15. National Aeronautics and Space 
Administration. Jet Propulsion Laboratory, California Institute of Technology, Pasadena, California, USA

Sanderson, M.G., Collins, W.J., Derwent, R.G., Johnson, C.E., 2003. Simulation of global hydrogen levels using a Lagrangian three-dimensional model. J. Atmos. Chem. 46, 15-28.

Schultz, M.G., Diehl, T., Brasseur, G.P., Zittel, W., 2003. Air pollution and climateforcing impacts of a global hydrogen economy. Science 302, 624-627.

Schultz, M.G., Markert, F., Pilegaard, K., 2004. Hydrogen and the environment. In: Larsen, H., Feidenhans, R., Sønderberg Petersen, L. (Eds.), Risø Energy Report 3 Hydrogen and Its Competitors. Risø National Laboratory, Risø, Denmark.

Sherif, S.A., Zeytinoglu, N., Veziroglu, T.N., 1997. Liquid hydrogen: potential, problems and a proposed research program. Int. J. Hydrogen Energy 22, 683-688.

Smit, R., Weeda, M., de Groot, A., 2007. Hydrogen infrastructure development in The Netherlands. Int. J. Hydrogen Energy 32, 1387-1395.

Specht, M., Staiss, F., Bandi, A., Weimer, T., 1998. Comparison of the renewable transportation fuels, liquid hydrogen and methanol, with gasoline - energetic and economic aspects. Int. J. Hydrogen Energy 23, 387-396.

Stiller, C., personal communication. E-mail conversation between C. Stiller (LBST) and B. van Ruijven, Bilthoven, February 2009.

Stiller, C., Svensson, A.M., Møller-Holst, S., Bünger, U., Espegren, K.A., Holm, Ø.B. Tomasgård, A., 2008. Options for CO2-lean hydrogen export from Norway to Germany. Energy 33, 1623-1633.

Tabkhi, F., Azzaro-Pantel, C., Pibouleau, L., Domenech, S., 2008. A mathematical framework for modelling and evaluating natural gas pipeline networks under hydrogen injection. Int. J. Hydrogen Energy 33, 6222-6231.

Thomas, C.E., James, B.D., Lomax, F.D., 1998. Market penetration scenarios for fuel cell vehicles. Int. J. Hydrogen Energy 23, 949-966.

Tie, X., Brasseur, G., Emmons, L., Horowitz, L., Kinnison, D., 2001. Effects of aerosols on tropospheric oxidants: a global model study. J. Geophys. Res. D: Atmos. 106 22931-22964.
Tie, X., Madronich, S., Walters, S., Edwards, D.P., Ginoux, P., Mahowald, N., Zhang, R.Y., Lou, C., Brasseur, G., 2005. Assessment of the global impact of aerosols on tropospheric oxidants. J. Geophys. Res. D: Atmos. 110, 1-32.

Tromp, T.K., Shia, R.L., Allen, M., Eiler, J.M., Yung, Y.L., 2003. Potential environmental impact of a hydrogen economy on the stratosphere. Science 300, 1740-1742.

van Ruijven, B., Hari, L., van Vuuren, D.P., de Vries, B., 2008. The potential role of hydrogen in India and Western Europe. Energy Policy 36, 1649-1665.

van Ruijven, B., van Vuuren, D.P., de Vries, B., 2007. The potential role of hydrogen in energy systems with and without climate policy. Int. J. Hydrogen Energy 32 1655-1672.

van Vuuren, D.P., van Ruijven, B.J., Hoogwijk, M.M., Isaac, M., de Vries, H.J.M., 2006. TIMER 2.0, Model description and application. In: Bouwman, A.F., Hartman, M.P.M., Klein Goldewijk, C.G.M. (Eds.), Integrated Modelling of Global Environmental Change. An Overview of IMAGE 2.4. Netherlands Environmental Assessment Agency (MNP), Bilthoven.

Vogel, B., Feck, T., Grooß, J.U., 2011. Impact of stratospheric water vapor enhancements caused by $\mathrm{CH} 4$ and $\mathrm{H} 2 \mathrm{O}$ increase on polar ozone loss. J. Geophys. Res. 116, D05301.

Wuebbles, D., 2008. Evaluation of the Potential Environmental Impacts from Largescale Use and Production of Hydrogen in Energy and Transportation Applications. University of Illinois.

Young, P.J., Arneth, A., Schurgers, G., Zeng, G., Pyle, J.A., 2009. The CO2 inhibition of terrestrial isoprene emission significantly affects future ozone projections. Atmos. Chem. Phys. 9, 2793-2803.

Zachariah, J.L., Hemmes, K., Bouwmans, I., Michels, J.P.J., Schouten, J.A., Janssen, R., 2004. Moving towards hydrogen via natural gas: implications for the Netherlands. In: International Gas Research Conference Proceedings.

Zittel, W., 2004. Atmospheric Impact of a Future Hydrogen Economy and Proposal for Hydrogen Emission Scenario Calculations, Presentation at the 1st HyCare workshop at the MPI-Hamburg. 